\title{
PENGARUH KEPUASAN NASABAH DAN KEPERCAYAAN NASABAH TERHADAP KINERJA PEMASARAN KANTOR LAYANAN PADA PT. BANK NEGARA INDONESIA (PERSERO) TbK KANTOR CABANG PERGURUAN TINGGI BANDUNG
}

Effect Of Customer Satisfaction And Trust To Performance Marketing Customer Service Office In PT. Bank Negara Indonesia (Persero) Tbk Higher Education Branch Office Bandung

Disusun Oleh :

Teti Kusmiati

NIM. 61.101.11.010

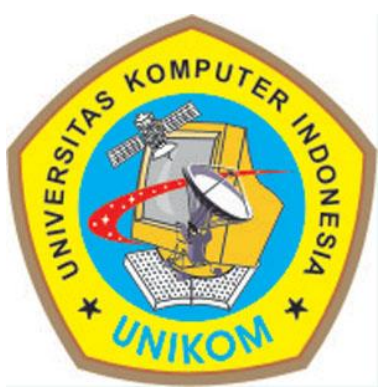

\author{
PROGRAM STUDI MAGISTER MANAJEMEN \\ PROGRAM PASCA SARJANA \\ UNIVERSITAS KOMPUTER INDONESIA \\ BANDUNG \\ 2013
}




\title{
PENGARUH KEPUASAN NASABAH DAN KEPERCAYAAN NASABAH \\ TERHADAP KINERJA PEMASARAN KANTOR LAYANAN PADA PT. BANK NEGARA INDONESIA (PERSERO) Tbk KANTOR CABANG PERGURUAN TINGGI BANDUNG
}

\author{
Effect Of Customer Satisfaction And Trust To Performance Marketing Customer Service Office In \\ PT. Bank Negara Indonesia (Persero) Tbk Higher Education Branch Office Bandung
}

\author{
Teti Kusmiati \\ Universitas Komputer Indonesia
}

\begin{abstract}
ABSTRAK
Studi ini meneliti adanya fenomena-fenomena yang diidentifikasi adanya kelemahan secara situasional dan kondisional di lapangan berkaitan kepuasan dan kepercayaan yang dirasakan oleh para nasabah terhadap kinerja pemasaran perbankan PT. Bank Negara Indonesia (Persero), Tbk di cabang Perguruan Tinggi Bandung.

Penelitian ini bertujuan untuk mengetahui Pengaruh Kepuasan Nasabah dan Kepercayaan Nasabah Terhadap Kinerja Pemasaran Kantor layanan Pada PT. Bank Negara Indonesia (Persero) Tbk di Cabang Perguruan Tinggi Bandung.

Objek penelitian ini adalah nasabah di PT. BNI (Persero) Tbk Cabang PTB Bandung sebagai unit analisis. Analisis yang digunakan di dalam penelitian ini, disandarkan pada analisis deskriptif dan verifikatif dengan menggunakan skor penelitian responden atau pelanggan berkaitan dengan variabel-variabel peneltiian, sedangkan untuk mengverifikasi di dalam menjawab hipotesis penelitian digunakan analisis structural equation modeling (SEM)

Hasil penelitian ini berdasarkan analisis diskriptif dengan menggunakan distribusi frekuensi, dapat menunjukkan akar permasalahan yang dihadapi PT. BNI (Persero) Tbk di kantor cabang Perguruan Tinggi Bandung, serta akan dilihat dari hipotesis pertama apakah perbankan layanan terhadap kepuasan dan kepercayaan nasabah berpengaruh terhadap kinerja pemasaran baik secara parsial maupun simultan.
\end{abstract}

Kata Kunci : Kepuasan Nasabah, Kepercayaan Nasabah dan Kinerja Pemasaran

\section{ABSTRACT}

This study examines the phenomena identified a weakness in situational and conditional on satisfaction and trust related field perceived by the customer to the bank PT marketing performance. Bank Negara Indonesia (Persero), Tbk in Bandung branch of Higher Education.

This study aims to determine the effect of Customer Satisfaction and Trust on Performance Marketing Customer Service Office at PT. Bank Negara Indonesia (Persero) Tbk Branch Higher Education in Bandung.

The research object is the client in the PT. BNI (Persero) Tbk Branch PTB Bandung as the unit of analysis. The analysis used in this study, was based on descriptive analysis and verification by using the scores of research respondents or customers in relation to research variables, whereas for verifications in the analysis used to answer the research hypothesis of structural equation modeling (SEM)

The results are based on descriptive analysis using frequency distribution, may indicate root problems faced by PT. BNI (Persero) Tbk in Higher Education Bandung branch offices, as well as will be seen from the first hypothesis whether banking services to the customers' satisfaction and trust affect the marketing performance either partially or simultaneously.

Keywords: Customer Satisfaction, Customer Confidence and Performance Marketing

Program Pascasarjana, Program Studi Magister Manajemen

Jl. Dipati Ukur No. 112-116 Bandung 40132

teti.kusmiati@mailbni.co.id 


\section{PENDAHULUAN}

Manajemen perbankan telah mengeluarkan ketentuan yang berlaku bagi semua personil bahwa dalam menjalankan aktivitas sehari hari diharuskan untuk menjalankan standar layanan dengan list perbankan yang berpedoman pada teori, konsep dan permodelan manajemen strategi dan pemasaran yang dapat mendukung pencapaian kinerja yang maksimal dan didukung oleh penerapan Business Banking atau Customer to Business sehingga sukses jangka panjang dalam pencapaian kinerja dapat diwujudkan oleh perbankan. Kini bisnis dalam lingkungan pemasaran dalam perbankan bersaing dinamis sejalan dengan perubahan lingkungan yang globalisasi. Tingkat persaingan antara bank yang semakin ketat, selera nasabah, kemajuan teknologi perbankan, serta perubahan social ekonomi memunculkan tantangan dan peluang dalam bisnis perbankan.

Bagi jasa perbankan yang terpenting adalah bagaimana memahami dan memenuhi kebutuhan nasabah serta keinginan nasabah, sehingga pihak bank dapat mengembangkan produk, tingkat harga, distribusi, promosi pelayanan petugas, proses pelayanan, dan penyediaan sarana fisik perbankan yang dapat memperluas pasar atau meningkatkan pangsa pasar perbankan. Untuk mendapat nasabah yang baru dan mempertahankan nasabah yang sudah ada perlu adanya komitmen yang tinggi baik menyangkut pengelolaan sumber daya manusia dan dukungan teknologi perbankan yang canggih agar kualitas produk bank benar-benar sesuai dengan keinginan nasabah dan dapat memberi kepuasan nasabah.

Dengan memberikan pelayanan superior baik melalui penerapan standar layanan dan peningkatan product knowledge dari semua personil di frontliner yang melakukan pelayanan kepada nasabah, mulai dari penerimaan greeting wal yang dilakukan oleh petugas satpam, kemudian waktu untuk menunggu dilayani dan informasi yang disampaikan oleh petugas customer service dari mulai buka rekening, handling complain sampai transaksi nasabah itu selesai dijalankan oleh petugas teller dan nasabah itu kembali pulang dengan sapaan greeting akhir semua petugas front liner tersebut, secara tidak langsung nasabah merasa puas dan percaya akan pelayanan bank itu sendiri. Bila pelayanan BNI tidak baik, maka sudah pasti BNI akan kalah bersaing oleh gelombang perubahan saat ini. Dengan strategi kinerja pemasaran yang terdiri dari produk, harga, tempat, dan standar pelayanan yang diterapkan BNI saat ini diharapkan mampu menjawab kepuasan nasabah dan dapat memberikan pelayanan superior kepada nasabah sehingga nasabah puas dan memelihara kepercayaan nasabah sehingga mampu mencapai target kinerja yang diharapkan.

\section{METODE PENELITIAN}

Metode penelitian yang digunakan adalah metode survei, yaitu penelitian yang dilakukan pada populasi besar maupun kecil, tetapi data yang diteliti adalah data sampel yang diambil dari populasi secara proporsional, sehingga ditemukan kejadian-kejadian relatif, distribusi dan hubungan-hubungan antar variabel sosiologis maupun psikologis (Sugiyono,2004:7). Singarimbun (1995;4) mengemukakan bahwa penelitian survey dapat digunakan untuk ; 1). Penjajagan 
(exploratif), 2). Deskriptif (description), 3). Penjelasan (explanatory), 4). Evaluasi, 5). Prediksi (meramalkan), 6).

Penelitian operasional dan pengembangan-pengembangan indikator sosial.

\section{a. Operasionalisasi Variabel}

Dalam penelitian ini yang menjadi variabel eksogen adalah kepuasan nasabah (X1) dan kepercayaan nasabah (X2) sedangkan variabel endogennya yaitu kinerja pemasaran (Y). Variabel-variabel tersebut akan diukur dengan instrumen pengukuran dalam bentuk kuesioner yang bersifat tertutup yang memenuhi Skala Likert. Untuk setiap pilihan jawaban diberi skor, dan skor yang diperoleh mempunyai tingkat pengukuran ordinal.

Variabel kepuasan nasabah (X1) terdiri dari 3 dimensi yaitu personnel interaction, pendukung secara fisik atau physic aspect, handling complain, policy, dan variabel kepercayaan (X2) terdiri dari 3 dimensi yaitu credibility, Benevolence, dan Trusworthines, serta variabel kinerja pemasaran jasa bank (Y) meliputi 3 dimensi yaitu: kualitas pelayanan, kinerja produk, dan nilai pelanggan.

\section{b. Populasi dan Sampel}

Populasi tidak lain adalah himpunan, sedangkan himpunan yang dimaksud dalam penelitian dapat berupa benda, manusia, gejala, peristiwa, atau hal-hal lain yang memiliki karakteristik tertentu untuk memperjelas masalah penelitian (Winarno, 1990; Kerlinger, 1995; dan Suharsimi, 1996). Sedangkan menurut Uma Sukaran (2000:266) populasi menunjukkan keseluruhan grup dan orang-orang, peristiwa atau barang-barang yang diminati dan ingin dikaji oleh peneliti untuk diselidiki. Dengan demikian populasi dalam penelitian ini meliputi keseluruhan pihak yang dijadikan sumber informasi bagi indikator-indikator yang mengukur setiap variabel, kinerja pemasaran bank, kepuasan nasabah dan kepercayaan nasabah.

Untuk memperoleh sampel yang representative, ada beberapa langkah yang akan dilakukan dalam penelitian ini. Pertama, menginventarisasi rata-rata jumlah Nasabah di BNI di bulan Desember 2012 Kedua, menentukan ukuran sampel dari besarnya populasi yang berupa jumlah nasabah bank BNI cabang PTB Bandung. Adapun jumlah nasabah bank BNI cabang PTB Bandung

\section{Ukuran Sampel Nasabah bank BNI cabang PTB Bandung di masing masing kantor layanan di bawah cabang PTB Bandung}

\begin{tabular}{|c|l|r|}
\hline No & \multicolumn{1}{|c|}{ Nama Kantor Layanan } & Jumlah Nasabah \\
\hline 1 & KCU Perguruan Tinggi Bandung & 37.061 \\
\hline 2 & Ganesha & 28.668 \\
\hline 3 & Politeknik ITB & 13.718 \\
\hline 4 & LIPI - ITB & 3.809 \\
\hline 5 & Cihampelas & 3.578 \\
\hline 6 & UNIKOM & 19.285 \\
\hline 7 & Universitas Padjajaran & 79.695 \\
\hline 8 & Jatinangor & 26,388 \\
\hline 9 & Dago & 9.566 \\
\hline 10 & Universitas Pendidikan Indonesia & 61.687 \\
\hline 11 & Lembang & 7.359 \\
\hline
\end{tabular}




\begin{tabular}{|r|l|r|}
12 & Sukajadi & 14.705 \\
\hline 13 & Itenas & 12.495 \\
\hline 14 & Universitas Maranatha & 8.979 \\
\hline 15 & Pasteur & 1.046 \\
\hline 16 & Setiabudhi $\quad$ Total & 1.405 \\
\hline \multicolumn{2}{|c|}{} & $\mathbf{3 2 9 . 4 4 4}$ \\
\hline
\end{tabular}

\section{c. Hasil dan Pembahasan}

Penarikan sampel ini dilakukan dengan menggunakan metode purposive sampling. Menurut Uma Sekaran (2000:279) purposive samplingadalah teknik penentuan sampel dengan pertimbangan tertentu, yaitu sampel diambil dari polulasi yang pernah menggunakan seluruh jasa kantor layanan di kantor cabang PTB Bandung. Jumlah populasi nasabah kantor layanan di BNI PTB Bandung rata-rata per tahun sebanyak 329.444 nasabah, dengan menetapkan presisi 5\% (0.05), maka diperoleh sampel sebagai berikut:

$$
\begin{aligned}
& n=\frac{329.444}{329.444(0.05)^{2}+1} \\
& n=99,75 \approx 100
\end{aligned}
$$

Ukuran sampel dengan demikian menjadi 100 nasabah, sebagai unit sampel yang dapat mewakili populasi bank BNI

Untuk mengetahui karakteristik responden pelanggan (nasabah) kantor layanan di bawah kantor cabang PTB Bandung selanjutnya akan dilihat dari jenis kelamin, usia, latar belakang pendidikan dan jenis pekerjaan.

\section{1) Kepuasan Pelanggan (Nasabah)}

Kepuasan nasabah diukur dengan empat sub variabel yaitu interaksi karyawan/personal,aspek pendukung fisik,penanganan complain dan kebijakan. Kepuasan nasabah merupakan tingkat perasaan seseorang yang dihasilkan dengan membandingkan kinerja dirasakan atas suatu perusahaan dengan harapannya terhadap perusahaan tersebut. Kepuasan nasabah tersebut dari keempat sub variabel hasil kategori masing masing sub variable dapat dilihat dari table deskriptif berikut ini :

Tabel Deskriptif Statistik Kepuasan Nasabah

\begin{tabular}{|c|c|c|c|c|c|c|c|c|c|c|c|c|}
\hline & $\mathrm{N}$ & Range & Min & $\max$ & \multicolumn{2}{|c|}{ Mean } & \multirow{2}{*}{$\frac{\text { Std. Dev }}{\text { Stat }}$} & \multirow{2}{*}{\begin{tabular}{|l} 
Var \\
Stat
\end{tabular}} & \multicolumn{2}{|c|}{ Skewness } & \multicolumn{2}{|c|}{ Kurtosis } \\
\hline & Stat & Stat & Stat & Stat & Stat & $\begin{array}{l}\text { Std. } \\
\text { Error }\end{array}$ & & & Stat & $\begin{array}{l}\text { Std. } \\
\text { Error }\end{array}$ & Stat & $\begin{array}{l}\text { Std. } \\
\text { Error }\end{array}$ \\
\hline $\begin{array}{l}\text { Valid N } \\
\text { (listwise) }\end{array}$ & $\begin{array}{l}100 \\
100 \\
100 \\
100 \\
100\end{array}$ & $\begin{array}{l}2.74 \\
3.29 \\
4.16 \\
3.10\end{array}$ & $\begin{array}{l}2.07 \\
1.79 \\
1.00 \\
1.46\end{array}$ & $\begin{array}{l}4.81 \\
5.08 \\
5.16 \\
4.57\end{array}$ & $\begin{array}{l}3.2574 \\
3.4144 \\
3.5881 \\
3.1560\end{array}$ & $\begin{array}{l}.05660 \\
.06308 \\
.07899 \\
.06613\end{array}$ & $\begin{array}{l}.56601 \\
.63078 \\
.78987 \\
.66133\end{array}$ & $\begin{array}{l}.320 \\
.398 \\
.624 \\
.437\end{array}$ & $\begin{array}{r}.174 \\
-.228 \\
-.492 \\
-.271\end{array}$ & $\begin{array}{l}.241 \\
.241 \\
.241 \\
.241\end{array}$ & $\begin{array}{r}-.594 \\
.624 \\
1.378 \\
-.225\end{array}$ & $\begin{array}{l}.478 \\
.478 \\
.478 \\
.478\end{array}$ \\
\hline
\end{tabular}

Descriptive Statistics

Berdasarkan pengolahan data pada tabel di atas diperoleh bahwa kepuasan nasabah berada dalam kategori moderat yaitu $\mathrm{X} 1=3.2574 ; \mathrm{X} 2=3.4144 ; \mathrm{X} 3=3.5881 ; \mathrm{X} 4=3.1560$ artinya rata rata dari keempat variable tersebut adalah 3.3540dan belum menunjukkan kepuasan yang tinggi bagi 
konsumen/nasabah. Dengan demikian dapat disimpulkan bahwa secara umum kepuasan nasabah jasa perbankan BNI yang meliputi interaksi personal, aspek pendukung fisik, penanganan komplain, dan kebijakan berada dalam kategori Sedang, rata-rata nasabah belum memiliki kepuasan yang tinggi.

Dengan menggunakan analisis uji rata-rata terhadap variabel kepuasan pelanggan perbankan BNI maka diperolah hasil seperti pada Tabel 4.2 Berdasarkan tabel tersebut menginidikasikan bahwa bahwa perbankan BNI belum memberikan kepuasan pelanggan. Hal ini ditunjukkan lebih tingginya harapan para nasabah dibandingkan dengan yang dirasakan di bank BNI. Kepuasan nasabah menunjukkan berada dalam kategori moderat yaitu $\mathrm{X} 1=3.2574 ; \mathrm{X} 2=3.4144 ; \mathrm{X} 3=3.5881 ; \mathrm{X} 4=3.1560$ artinya rata rata dari keempat variable tersebut adalah 3.3540, dan belum menunjukkan kepuasan yang tinggi bagi konsumen/nasabah.

2) Kepercayaan Nasabah

Tingkat kepercayaan nasabah diukur melalui indikator trust yang meliputi : Credibility, Benevolence, dan Trustworthines. Kepercayaan nasabah tersebut dari ketiga sub variabel hasil kategori masing masing sub variable dapat dilihat dari table deskriptif berikut ini :

Tabel Deskriptif Statistik Kepercayaan Nasabah

\begin{tabular}{|c|c|c|c|c|c|c|c|c|c|c|c|c|}
\hline & $\mathrm{N}$ & Range & Minim & Maxi & \multicolumn{2}{|c|}{ Mean } & \multirow{2}{*}{\begin{tabular}{|c} 
Std. \\
Devia \\
tion
\end{tabular}} & \multirow{2}{*}{$\begin{array}{l}\text { Vari } \\
\text { ance } \\
\text { Stati } \\
\text { stic }\end{array}$} & \multicolumn{2}{|c|}{ Skewness } & \multicolumn{2}{|c|}{ Kurtosis } \\
\hline & $\begin{array}{c}\text { Statis } \\
\text { tic }\end{array}$ & $\begin{array}{c}\text { Statisti } \\
\text { c }\end{array}$ & $\begin{array}{c}\text { Statis } \\
\text { tic }\end{array}$ & $\begin{array}{c}\text { Statis } \\
\text { tic }\end{array}$ & $\begin{array}{c}\text { Statisti } \\
\mathrm{c}\end{array}$ & $\begin{array}{l}\text { Std. } \\
\text { Error }\end{array}$ & & & $\begin{array}{l}\text { Stati } \\
\text { stic }\end{array}$ & $\begin{array}{l}\text { Std. } \\
\text { Error }\end{array}$ & $\begin{array}{l}\text { Stati } \\
\text { stic }\end{array}$ & $\begin{array}{l}\text { Std. } \\
\text { Error }\end{array}$ \\
\hline X5 & 100 & 2.70 & 1.82 & 4.52 & 3.3548 & .05517 & $\begin{array}{r}.5516 \\
6\end{array}$ & .304 & $\begin{array}{r}- \\
.097\end{array}$ & .241 & $\begin{array}{r}- \\
.062\end{array}$ & .478 \\
\hline$x 6$ & 100 & 2.90 & 2.25 & 5.15 & 3.3042 & .04914 & $\begin{array}{r}.4914 \\
5\end{array}$ & .242 & .466 & .241 & $\begin{array}{r}1.17 \\
4\end{array}$ & .478 \\
\hline $\begin{array}{l}\mathrm{X7} \\
\text { Valid N } \\
\text { (listwise) }\end{array}$ & 100 & 2.47 & 2.00 & 4.47 & 3.2160 & .05027 & $\begin{array}{r}.5026 \\
6\end{array}$ & .253 & .009 & .241 & $\begin{array}{r}- \\
.595\end{array}$ & .478 \\
\hline
\end{tabular}

Berdasarkan pengolahan data pada tabel di atas diperoleh bahwa kepercayaan nasabah perusahaan jasa perbankan berada dalam kategori moderat yaitu yaitu $\mathrm{X}_{5}=3.3548 ; \mathrm{X}_{6}=3.3042 ; \mathrm{X}_{7}=3.2160$ artinya rata rata dari keempat variable tersebut adalah 3.2917 dan belum menunjukkan kepercayaan yang tinggi bagi konsumen/ nasabah. Dengan demikian dapat disimpulkan bahwa secara umum kepercayaan nasabah perbankan yang meliputi Credibility, Benevolence, dan Trustworthines berada dalam kategori Sedang moderat, rata-rata nasabah belum memiliki kepercayaan yang tinggi. 


\section{3) Kinerja Pemasaran}

Tingkat kinerja pemasaran perbankandapat diukur melalui indikator kinerjayang meliputi: kualitas pelayanan, kinerja produk, dan nilai pelanggan. Kinerja pemasaran perbankan tersebut terdiri dari ketiga sub variabel hasil kategori masing masing sub variable dapat dilihat dari table deskriptif berikut ini :

Tabel Deskriptif Statistik Kinerja Pemasaran perbankan

\begin{tabular}{|c|c|c|c|c|c|c|c|c|c|c|c|c|}
\hline & $\mathrm{N}$ & Ran & Mini & Maxi & \multicolumn{2}{|c|}{ Mean } & \multirow{2}{*}{$\begin{array}{c}\text { Std. } \\
\text { Deviati } \\
\text { on } \\
\begin{array}{c}\text { Statisti } \\
\text { c }\end{array} \\
\end{array}$} & \multirow{2}{*}{$\begin{array}{l}\text { Vari } \\
\text { ance } \\
\text { Stati } \\
\text { stic }\end{array}$} & \multicolumn{2}{|c|}{ Skewness } & \multicolumn{2}{|c|}{ Kurtosis } \\
\hline & $\begin{array}{l}\text { Stati } \\
\text { stic }\end{array}$ & $\begin{array}{l}\text { Stati } \\
\text { stic }\end{array}$ & $\begin{array}{l}\text { Stati } \\
\text { stic }\end{array}$ & $\begin{array}{l}\text { Stati } \\
\text { stic }\end{array}$ & $\begin{array}{c}\text { Statisti } \\
\text { c }\end{array}$ & $\begin{array}{l}\text { Std. } \\
\text { Error }\end{array}$ & & & $\begin{array}{c}\text { Statis } \\
\text { tic }\end{array}$ & $\begin{array}{l}\text { Std. } \\
\text { Error }\end{array}$ & $\begin{array}{c}\text { Statis } \\
\text { tic }\end{array}$ & $\begin{array}{l}\text { Std. } \\
\text { Error }\end{array}$ \\
\hline Y1 & 100 & 3.51 & 1.29 & 4.81 & 3.0749 & .07711 & .77105 & .595 & .416 & .241 & -.258 & .478 \\
\hline Y2 & 100 & 3.36 & 1.86 & 5.22 & 3.3709 & .07582 & .75822 & .575 & .554 & .241 & .010 & .478 \\
\hline $\begin{array}{l}\text { Y3 } \\
\text { Valid N } \\
\text { (listwise) }\end{array}$ & $\begin{array}{l}100 \\
100\end{array}$ & 3.57 & 1.45 & 5.02 & 3.2702 & .07472 & .74715 & .558 & .240 & .241 & -.149 & .478 \\
\hline
\end{tabular}

Pada tabel diatas dapat dilihat bahwa yaitu nilai load rata rata menunjukkan $\mathrm{Y}_{3}=3.2702$ memberikan penilaian yang cukup terhadap Customer value yang mencakup kesungguhan perbankandalam melayanani dengan sebaik baiknya terhadap para nasabah dari berbagai kalangan masyarakat. Disamping itu perbankan senantiasa memenuhi nilai pelanggan, seperti menyampaikan jasa sesuai dengan keinginan nasabah demi mempertahankan reputasi leader pemimpin dunia perbankan.

Berdasarkan analisa verfikatif didapatkan persamaan structural sebagai berikut :

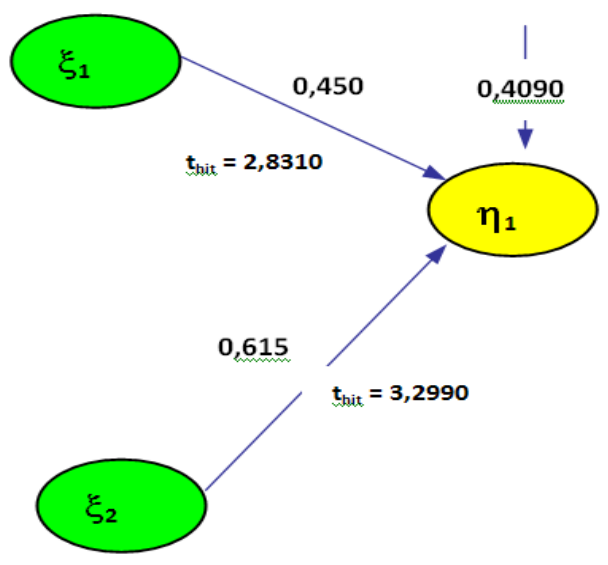

Untuk mengetahui korelasi ganda dan besarnya pengaruh secara bersama-sama kepuasan dan kepercayaan terhadap kinerja pemasaran dapat dilihat nilai korelasi dan koefisien determinasi $\left(\mathrm{R}^{2}\right)$. Tabel berikut merupakan hasil perhitungan koefisien determinasi untuk persamaan regresi yang diperoleh dengan SPSS 20 for windows sebagai berikut : 
Model Summaryb

\begin{tabular}{|l|r|r|r|r|r|}
\hline Model & R & R Square & \multicolumn{1}{c|}{$\begin{array}{c}\text { Adjusted R } \\
\text { Square }\end{array}$} & $\begin{array}{c}\text { Std. Error of the } \\
\text { Estimate }\end{array}$ & Durbin-Watson \\
\hline 1 & $.668^{\mathrm{a}}$ & .446 & .434 & .52272 & 1.833 \\
\hline
\end{tabular}

a. Predictors: (Constant), Kepercayaan, Kepuasan

b. Dependent Variable: Kinerjal

Secara bersama-sama variabel Kepuasan nasabah dan Kepercayaan nasabah dapat menjelaskan perubahan yang terjadi pada kepuasan pelanggan sebesar 44,60\% dan sisanya dijelaskan oleh faktorfaktor lain yang tidak ditelti. Artinya antara perubahan dalam kepuasandan kepercayaan akan sangat berkaitan dengan kinerja pemasaran. Diantara kedua variabel eksogen, kepercayaan nasabahmemberikan kontribusi $61.50 \%$ terhadap Kinerja pemasaran.

Kesimpulannya bahwa secara parsial dan simultan Kepuasan nasabah dan kepercayaan nasabah berpengaruh terhadap kinerja pemasaran secara signifikan. Artinya $\mathrm{H}_{0}$ di tolak dan $\mathrm{H}_{1}$ diterima. $\mathrm{Hal}$ ini memberikan makna dimana kepuasan nasabah dan kepercayaan nasabah merupakan komponen penting dalam pemasaran sehingga mampu mendorongkinerja pemasaran perbankan akan lebih baik lagi.

\section{Kesimpulan dan Saran}

\section{Kesimpulan}

Berdasarkan hasil analisis terhadap kepuasan nasabah dan kepercayaan nasabah yang dilakukan di kantor layanan pada PT. BNI (Persero), Tbk Kantor Cabang Perguruan Tinggi Bandung dengan 100 nasabah umum, nasabah mahasiswa dan nasabah layanan prima, diperoleh kesimpulan sebagai berikut :

1. Kepuasan nasabah berpengaruh terhadap kinerja pemasaran pada Bank BNI Cabang Perguruan Tinggi Bandung

2. Kepercayaan nasabah berpengaruh terhadap kinerja pemasaran.

\section{Saran}

Berdasarkan hasil pembahasan dan kesimpulan penelitian maka diajukan beberapa saran-saran sebagai berikut :

a. Perlunya pembenahan dan perbaikan terus menerus untuk dimensi kinerja pemasaran hal ini disebabkan masih banyaknya indikator-indikator kinerja pemasaran dari setiap petugas pemasaran dan dirasakan lemah oleh pihak nasabah terutama dalam hal waktu memberikan layanan pada nasabah.

b. Perlunya pembenahan dan perbaikan terus menerus serta meninjau kembali kebijakan yang berkaitan dengan pelayanan pada nasabah, hal ini disebabkan masih banyaknya indikator-indikator kinerja pemasaran masingmasing kantor pelayanan dirasakan lemah oleh pihak nasabah, hal ini berkaitan erat dengan kepentingan nasabah 
akan nilai konsumen yang unggul serta biaya relatif rendah dan kedua atribut tersebut merupakan manfaat yang seharusnya dapat dinikmati oleh para calon nasabah

c. Perlunya pembenahan dan perbaikan terus menerus untuk kepuasan nasabah, hal ini disebabkan masih banyaknya indikator kepuasan nasabah dari setiap petugas masing-masing kator layanan dirasakan lemah oleh pihak nasabah, hal ini berkaitan erat dengan kepentingan nasabah akan kredibilitas dan ketulusan petugas selama dilayani.

d. Perlunya perbaikan terus menerus dan memperhatikan dimensi kepercayaan nasabah hal ini disebabkan masih banyaknya indicator-indikator kepercayaan nasabah dari setiap operator masing-masing nasabah dirasakan lemah oleh pihak nasabah hal ini berkaitan erat dengan kepentingan para nasabah akan kejujuran, ketulusan serta ketiga atribut tersebut merupakan komponen penting untuk memberikan pelayanan yang lebih prima kepada nasabah selama dilayani

e. Untuk pihak regulator dalam hal ini pemerintah, perlunya terus menerus pembenahan pada dimensi prasaran, sarana serta system teknologi perbankan berkaitan erat dengan kualitas pelayanan yang pada akhirnya akan tercipta kepercayaan kinerja yang diharapkan seluruh masyarakat pengguna jasa perbankan.

f. Bagi peneliti selanjutnya dapat mengembangkan penelitian pada dimensi-dimensi pengembangan sumber daya manusia terutama dalam hal training and development para pegawai khususnya di PT. BNI Kantor Cabang Perguruan Tinggi Bandung agar lebih cermat dan teliti dalam melayani nasabahnya.

\section{DAFTAR PUSTAKA}

Achmad Bachrudin, dan Harapan L. Tobing. 2003. Analisis Data Untuk Penelitian Survey Dengan Menggunakan LISREL 8. Bandung : Jurusan Statistika FMIPA UNPAD

Alida Palilati. 2004. Pengaruh Tingkat Kepuasan Terhadap Loyalitas Nasabah Tabungan Perbankan Di Wilayah Etnik Bugis. Jurnal Analisis Maret Vol. 1 No. 2 Melalui. http://.pascaunhas.net/jurnal_pdf/an_1_2/alida-2.pdf

Best, Roger J., 2000. “Market-Based Management Strategies for Growing Customer Value and Prifitability”. New Jersey : Prentice Hall

Cravens, David W., and Nigel F. Piercy. 2003. Strategic Marketing, New York : McGraw Hill

Day, George S. 1999. “Market Driven Strategy : Processes For Creating Value”. New York : Free Press : London : Collier MacMillion

Dephub. 2006. "Statistik Penumpang Angkutan Udara Dalam Negeri dan Luar Negeri." Melalui. http://www.dephub.go.id/udara/statistik.htm

Diah Natalisa. 2000. Pengaruh Komitmen Manajemen Terhadap kualitas Layanan Untuk Meningkatkan Kepuasan Pelanggan Maskapai Penerbangan Domestik : Sudut Pandang Pelanggan dan Penyaji Jasa. Disertasi ilmu ekonomi, Surabaya : program Pascasarjana Universitas Airlangga

Daniel Chan. 2000. The Development of The Airline Industry from 1978 to 1998 : A Strategic Global Overview. The Joutnal of Management Development Volume 19 Number 62000 pp. 489 - 514

Egan. John. 2001. Relationship Marketing : Exploring Relational Strategies in Marketing. Prentice Hall. $\mathrm{Nj}$

Eggert, A. \& Ulaga. W. 2002.Customer perceived value : a substitute for satisfaction in business markets. The Journal of Business \& Industrial Marketing. Vol. 17 No. 2/3 2002 pp. 107 - 118 Copyright (C MCB University Press ISSN 0885 - 8624

Farida Jasfar. 2005. “Manajemen Jasa. Pendekatan Terpadu”. Bogor : Ghalia Indonesia 
Fandy Tjiptomo. 1999. Strategy Pemasaran. Yogyakarta : Andi

Tjiptono, dan Gregorius Chandra. 2005. ”Service Quality and Satisfaction”.Yogyakarta : ANDI

Hansen Don R., and Maryanne M. Mowen. 2005. Management Accounting $7^{\text {th }}$ Edition. South-Western of Thomson Learning. Penerjemah. Dewi Fitriasari, dan Denny Arnos Kwary. Jakarta : Salemba Empat.

James J. Zhoba and Clay M. Voorhees. 2006.The impact of brand trust and satisfaction. Joornal of Services Marketing. Volume 20. Number. 5 p.381 - 390

Joreskog, K.G., and Sorbom, D. 1996. “LISREL, 8 : User's Reference Guide, Chicago : Scientific Sofware International, Inc.

Kesper, Hans. 1999. Service Marketing Management. An International Perspective. New York : Jhon Wiley \& Sons.

Kelloway, E.K. 1998. Using LISREL for structural equation modeling : A research's guide. Thousand Oaks, Ca : Saga Publications, Inc

Kotler Philip and Gary Amstrong. 2006. "Principles Management”, New Jersey : Eleventh Edition, Pearson Prentice .2000. “Marketing Management”. New Jersey : The Millenium Edition, Prentice Hall International Inc. and Kevin Lane Keller. 2006. “Maketing Management”. Twelfth Edition. Pearson Prentice.

Lena Ellitan dan Lina Anatan. 2007. Strategi Bersaing dalam Service Driven Economy. Yogyakarta : Andi

Lewis, Barbara R., and Sotiris Spyrakopoulos. 2001. Service Failures and Recovery In Retail Banking : the Customer's Perspective. The International Journal of Bank Marketing Volume 19 Number pp. 37-38. Melalui. http://www.emeraldinsight.com/Insight/html/Output/Published/EmeraldFullTextArticle/Pdf/0320190103.pdf

Lovelock Christopher H. 2001. Service Marketing and Management; Second Edition. Newyork : Prentice Hall Internatioal and Lauren Wright. 2002. Principles of Service Marketing and Management. Second Edirion. New Jersey : pearson Education. Inc; Upper Saddle River. and Wirtz Jochen, Hean Tat Keh, Xiongwen Lu,. 2005. Services Marketing In Asia. Second Edition. Pearson Education, Prentice Hall

Lee, Sook Han and Lau, Geok Theng, 1999, Consumers' Trust in a Brand and The Link to Brand Loyalty, Journal of Market Focused Zanagement, 4, 341-370, Boston : Kluwer Academic Publishers. Melalui, http://www.springerlink.com/index/L480730T35182442.pdf

Matear : Brendan J Gray; Tony Garrett. 2004. Market Orientation, Brand investment, New Service Development, Market Position \& Performance for Service Organisations. International Journal of Service Industry Management, Volume 15, Number 3, pp. 284-301.

Masri Singarimbun dan Effendi Sofyan. 1995. Metode Penelitian Survai Jakarta : LP3ES.

Mason J Keith (2000). "Marketing low cost airline services to business travelers".

Melalui, : https://dspace.lib.cranfield.ac,uklbitsti-ecim/1826/911/2/JATM2000_V2.pdf

Melewar, T.C. and Saunders, J. 2000. Global Corporate Visual Identity Systems: Using an Extended Marketing Mix, European Journal of Marketing, Vol. 34 Number 5/6, pp. 538-550.

Michell P., Reast, J. and Lynch, J. 1998. Exploring the foundations of trust.

Mowen, John C., 1995. Customer Satisfaction, USA: Prentice Hall.

Moh. $\quad$ Nazir, $1988 . \quad$ Metode Penelitian. Jakarta: Cetakan ketiga. Ghalia Indonesia.

Muhtosim Arief, 2006. “Pemasaran Jasa \& Kualitas Pelayanan”, Malang: Bayumedia Publishing.

Muhtosim Arief, 2004. Pengaruh Keputusan Konsumen Pasca Penggunaan Jasa Terhadap Penanganan Komplain dan Dampaknya pada keterikatan Konsumen. Disertasi Ilmu Ekonomi, Bandung: Program Pascasarjana. Universitas Padjadjaran.

Oliver, Richard L., 1997. Satisfaction.' A Behavioral Perspective of the Cunsumer, McGraw Hill. New York, NY.

Patterson, P.G. and T. Ward, 2000. "Relationship Marketing and Management" in Swartz, T. A. and D. Lacobucci (eds), Handbook of Services Marketing and Management. Thousand Oaks: Sage Publications, Inc.

Payne, Adrian. 1993. "The Essence of Service Marketing", New York, Prentice Hal, Inc.'Penerjemah: Fandy Tjiptono, Yogyakarta: Andi.

Parasuraman, A. V.A Zeithaml., and L.L Berry., (1995). "A Conceptual Model of Service Quality and It's Implication for 
Future Research", Journal of Marketing, Vol. 49, 415. Melalui, <http:// www.emeraldinsight.com/Insight/ViewContentServiet?Filename=/publish ed/emeraldfulltextarticle/pdf

Porter, Michael .E., 1991. "Competitive Strategy, Technique For Analyzing Industries and Competitors", Mc Milan Publishing Co, Inc. New York Ratih Hurriyati, 2005. "Bauran Pemasaran dan Loyalitas Konsumen", Bandung:Alfabeta

Rust, Roland T., Anthony J. Zahorik dan Timothy L. Keiningham (1996), Service Marketing, Newyork: Harper Collins College Publishers.

Rapert, Molly., and Brent, Wren. 1998, Service quality as a competitive opportunity, Journal of Services Marketing, 12(3). Journal of Services Marketing, Inc., PO BOx 3000, Dept P, Denville, NJ 07834. Melalui, http://www.emerald1nsight.com/1nsight/ViewContentServlet?Fllellame=/ published/emeraldfulitextarticle/pdf

Reichheld, F.F. and P. Schefter, "E-Loyalty: Your Secret Weapon on the Web," Harvard Business Review (July--Aug. 2000), Vol. $\quad 78, \quad$ No. 4:105-113, 2000. www.emeraldinsight.com/Insiglit/html/Output/Published/EmeraldFullTextArticle/Pdf>

Sekaran, Uma. 2000. Research Method for-Business, A Skill-Building. Third Edition. John Willey \& Sons. Inc.

Solomon, Michael R, 1996, Customer Behavior, PrenticeHall, New Jersev.

Sucherly. 2003. Peranan Manqjemen Pemasaran Stratejik dalam Mnciplakan Keunggulan Posisional Serta Implikasinya terhadap Kinerja Organisasi Bisnis dan Non Bisnis, Pidato Pengukuhan Jabatan Guru Besar dalam IlmuEkonomi pada FE UNPAD: Bandung

Suharsimi Arikunto, 1996. Prosedur Penelitian Suatu Pendekatan Praktek, Rineka Cipta, Jakarta 